\title{
PENGARUH KOMBINASI PUPUK KANDANG DAN PUPUK MAJEMUK SERTA DOSIS ARANG SEKAM PADA PERTUMBUHAN DAN PRODUKSI CABAI RAWIT HIBRIDA (Capsicum annum L.)
}

THE EFFECT OF COMBINATION ORGANIC FERTILIZER WITH COMPOUND FERTILIZER AND DOSAGE HUSK CHARCOAL ON GROWTH AND PRODUCTION OF HYBRID CAYENNE PEPPER (Capsicum annum L.)

\author{
Widya Aliv Pakerti $^{1 *}$, D.W. Widjajanto ${ }^{1}$, Eny Fuskhah ${ }^{1}$ \\ ${ }^{1}$ Program Studi Agroekoteknologi, Fakultas Peternakan dan Pertanian, Universitas Diponegoro \\ Jl. Prof. Soedarto No. 50275, Tembalang, Kec. Tembalang, Kota Semarang, Jawa Tengah, Indonesia
}

\begin{abstract}
ABSTRAK
Tujuan penelitian adalah untuk mengetahui pengaruh dosis kombinasi pupuk kandang dan pupuk majemuk serta dosis arang sekam, serta interaksi ke dua perlakuan terhadap pertumbuhan dan produksi cabai rawit hibrida. Rancangan penelitian yang digunakan adalah rancangan acak lengkap pola faktorial (4x6) dengan 3 ulangan. Faktor pertama (A) dosis arang sekam yaitu A0 = kontrol, A1 = $40 \mathrm{~g}$ arang sekam $/ 8 \mathrm{~kg}$ tanah, $\mathrm{A} 2=80 \mathrm{~g}$ arang sekam $/ 8 \mathrm{~kg}$ tanah, $\mathrm{A} 3=120 \mathrm{~g}$ arang sekam $/ 8 \mathrm{~kg}$ tanah. Faktor kedua (B) dosis kombinasi pupuk kandang dan pupuk anorganik majemuk yaitu B0 $=$ kontrol, B1 $=100 \%$ pupuk kandang, $\mathrm{B} 2=75 \%$ pupuk kandang $+25 \%$ pupuk majemuk, $\mathrm{B} 3=50 \%$ pupuk kandang $+50 \%$ pupuk majemuk, $\mathrm{B} 4=25 \%$ pupuk kandang $+75 \%$ pupuk majemuk dan $\mathrm{B} 5=100 \%$ pupuk majemuk. Parameter yang diamati adalah tinggi tanaman, jumlah buah per tanaman, bobot buah per tanaman, berat segar tanaman, indeks panen. Data yang diperoleh dianalisis dengan ANOVA dan pada perlakuan yang berbeda dilakukan uji lanjut dengan DMRT. Hasil penelitian menunjukkan bahwa pemberian dosis kombinasi pupuk kandang dan pupuk majemuk secara keseluruhan berpengaruh nyata terhadap parameter yang diamati. Pemberian $25 \%$ pupuk kandang $+75 \%$ pupuk majemuk dan penggunaan arang sekam 120 $\mathrm{g} / 8 \mathrm{~kg}$ tanah memberikan hasil yang baik pada pertumbuhan dan produksi cabai rawit.
\end{abstract}

Kata kunci: Arang Sekam, Pupuk Kandang, Pupuk Majemuk.

\section{ABSTRACT}

The experiment was aimed to determine the effect of combination dosage organic fertilizer with compound fertilizer and dosage husk charcoal, also the interaction both of treatment on the growth and production of hybrid cayenne pepper. A completely randomized factorial design (4x6) with 3 replications was used throughout the experiment. The first factor was dosage husk charcoal (A) namely AO=control, $A 1=40 \mathrm{~g}$ husk charcoal/8 kg soil, $A 2=80 \mathrm{~g}$ husk charcoal/8 $\mathrm{kg}$ soil, $A 3=120 \mathrm{~g}$ husk charcoal $/ 8 \mathrm{~kg} \mathrm{soil}$. The second factor was combination dosage of organic fertilizer and compound fertilizer $(B)$ namely $B 0=$ control, $B 1=100 \%$ organic fertilizer, $B 2=75 \%$ organic fertilizer $+25 \%$ compound fertilizer, $B 3=50 \%$ organic fertilizer $+50 \%$ compound fertilizer, $B 4=25 \%$ organic fertilizer $+75 \%$ compound fertilizer dan $B 5=100 \%$ compound fertilizer. Parameters observed were plant height, total number of fruits per plant, total weight of fruits per plant, fresh weight per plant, harvest index. Collected data were analyzed using ANOVA and Duncan Test was employed for further analysis. Experiment showed that application of combination dosage organic fertilizer and compound fertilizer was significantly affected the observed parameters. Application of $25 \%$ organic fertilizer $+75 \%$ compound fertilizer and the use of $120 \mathrm{~g}$ husk charcoal/8 kg soil gave good result on growth and production of cayenne pepper.

\section{Keywords : Husk Charcoal, Organic Fertilizer, Compound Fertilizer}

\footnotetext{
${ }^{*}$ Penulis Korespondensi.

E-mail: widyaalif13@gmail.com

Telp: +62-085227158299
} 


\section{Pendahuluan}

Produksi tanaman cabai rawit di Indonesia mulai dari tahun 2015 sampai dengan tahun 2019 terus mengalami kenaikan, berturut-turut 869,94 ton (2015); 915,99 ton (2016); 1153,16 ton (2017); 1335,6 ton (2018); dan 1374,21 ton (2019) (BPS, 2020).

Meskipun produksi tanaman cabai rawit terus mengalami kenaikan, namun upaya untuk mempertahankan dan peningkatan produksi secara bertahap harus terus dilakukan guna memenuhi kebutuhan konsumen yang terus meningkat tiap tahunnya. Suplai nutrisi melalui pemupukan menjadi salah satu cara dalam meningkatkan produktivitas tanaman. Proses pemupukan untuk kesuburan tanah dan mendapatkan hasil maksimal dari suatu tanaman perlu memperhatikan beberapa hal yaitu jenis atau macam pupuk yang digunakan, dosis pemupukan, cara pemupukan dan kebutuhan pupuk bagi tanaman (Milla et al., 2016).

Pemupukan dapat menggunakan pupuk organik dan pupuk anorganik. Pupuk organik salah satunya yaitu pupuk kandang merupakan pupuk ramah lingkungan dengan beragam kandungan unsur hara namun memiliki kadar yang rendah dan lamban tersedia bagi tanaman. Pupuk organik juga mampu memperbaiki sifat fisik, sifat kimia dan sifat biologi tanah. Pupuk anorganik memiliki keunggulan mudah larut dalam air, kadar unsur haranya tinggi dan mudah diabsorbsi oleh akar. Pupuk growmore adalah jenis pupuk daun berwarna biru, berbentuk kristal dengan kandungan unsur hara yang lengkap dan memiliki sifat mudah larut dalam air (Lubis, 2017), sehingga dapat diaplikasikan melalui daun dengan cara dilarutkan dalam air. Penggunaan pupuk anorganik untuk tanaman perlu diperhatikan yakni dengan takaran atau dosis yang sesuai bagi kebutuhan tanaman serta diimbangi dengan penggunaan pupuk organik.

Pertumbuhan tanaman yang optimal selain memperhatikan suplai nutrisi juga dapat ditunjang dengan penggunaan media tanam yang baik. Media tanam yang digunakan dapat berupa campuran tanah dengan bahan organik salah satunya yaitu arang sekam padi. Sekam padi adalah limbah yang dihasilkan dari proses penggilingan padi yang keberadaannya melimpah dan cukup sulit terdekomposisi. Upaya untuk memanfaatkan limbah sekam padi yaitu dengan digunakan sebagai campuran dalam media tanam baik berupa sekam padi ataupun arang sekam padi. Aplikasi arang sekam padi 20 ton/ha memberikan pengaruh nyata pada panjang tanaman, jumlah daun, diameter umbi, jumlah umbi dan hasil panen pada tanaman bawang merah (Aini dan Wardiyati, 2018). Arang sekam memiliki sifat yang remah dan mudah menyerap air. Porositas arang sekam yang tinggi akan memperbaiki sirkulasi air dan udara dalam media tanam sehingga meningkatkan pemanjangan dan perkembangan akar (Agustin et al., 2014). Damayanti et al. (2019) melaporkan bahwa media tanam tanah + arang sekam padi dengan level dosis $200 \mathrm{~kg} \mathrm{~N} / \mathrm{ha}$ dalam bentuk pupuk kandang kambing secara nyata berpengaruh terjadap pertumbuhan dan produksi sawi pakcoy (Brassica rapa L.) dibanding perlakuan media tanam tanah dan tanah + sabut kelapa.

Penelitian bertujuan untuk mengkaji pengaruh dosis arang sekam dan pengaruh dosis kombinasi pupuk kandang dengan pupuk majemuk, serta mengkaji pengaruh interaksi kedua perlakuan terhadap pertumbuhan dan produksi cabai rawit hibrida.

\section{Metode Penelitian}

Penelitian telah dilaksanakan pada 24 Agustus 2020 - 11 Januari 2021 di Green House dan Laboratorium Ekologi dan Produksi Tanaman, Departemen Pertanian, Fakultas Peternakan dan Pertanian, Universitas Diponegoro, Semarang, Jawa Tengah. Lokasi penelitian berada pada posisi geografis $6^{\circ} 55^{\prime} 34^{\prime \prime}$ - $7^{\circ} 07^{\prime} 04^{\prime \prime} \mathrm{LS}$ dan $110^{\circ} 16^{\prime} 20^{\prime \prime}$ $110^{\circ} 30^{\prime 2} 29^{\prime \prime} \mathrm{BT}$ dengan ketinggian tempat 125 meter diatas permukaan laut ( $\mathrm{m} \mathrm{dpl}$ ), dengan rata-rata suhu udara harian berkisar antara $27-34^{\circ} \mathrm{C}$ pada siang hari dan $22-24^{\circ} \mathrm{C}$ pada malam hari, dan rata-rata kelembaban udara sebesar 75\% (BPS, 2015). Bahan - bahan yang digunakan adalah cabai rawit varietas Dewata 43 F1, arang sekam, pupuk kandang sapi, pupuk majemuk Growmore (20:20:20). Alat yang digunakan dalam penelitian adalah cangkul, bak semai, sekop, gembor, selang air, meteran, pot plastik ukuran 40 x $40 \mathrm{~cm}$, timbangan duduk kapasitas $10 \mathrm{~kg}$, gelas ukur, timbangan analitik, label, plastik, kamera, dan alat tulis.

Penelitian dilaksanakan dengan mempersiapkan media tanam dilakukan dengan pengambilan tanah di lahan kebun belakang Student Center, Universitas Diponegoro, Kecamatan Tembalang, Kota Semarang, Provinsi Jawa Tengah. Tanah diambil kemudian dikeringanginkan lalu tanah ditimbang sebanyak $8 \mathrm{~kg}$ dan dimasukkan ke dalam pot plastik berukuran $40 \times 40 \mathrm{~cm}$. Aplikasi arang sekam dilakukan pada 1 minggu sebelum tanam dengan cara dicampurkan dengan tanah hingga homogen. Penyemaian benih cabai rawit dilakukan pada media tanah di dalam bak semai. 
Penanaman bibit cabai rawit dilakukan saat bibit berumur 21 hari dengan ciri bibit telah memiliki 3 4 helai daun. Penanaman bibit dilakukan pada sore hari dengan cara menanam 1 bibit per plot plastik. Aplikasi pupuk kandang dilakukan pada 1 minggu sebelum tanam dan disesuaikan dengan perlakuan yaitu disetarakan dengan kebutuhan fosfor tanaman cabai rawit $110 \mathrm{~kg} \quad \mathrm{P}_{2} \mathrm{O}_{5} / \mathrm{ha}$. Pupuk majemuk growmore diberikan 2 minggu setelah tanam (MST) setiap 3 hari sekali. Aplikasi pupuk growmore sesuai perlakuan yang disetarakan dengan kebutuhan fosfor tanaman cabai rawit.

Pemeliharaan cabai rawit dilakukan dengan cara penyiraman tanaman dilakukan pada pagi dan sore hari. Pemasangan ajir saat tanaman berumur 21 HST, pengendalian gulma dan hama belalang secara mekanik.

Pemanenan dilakukan saat tanaman berumur 64 HST dengan ciri utama buah berwarna merah mengkilap. Panen dilakukan sebanyak 3 kali selama masa panen. Setelah habis masa panen tajuk dan akar tanaman cabai rawit dipanen untuk dianalisis berat segar tanaman.

Parameter yang diamati adalah tinggi tanaman, jumlah buah per tanaman, bobot buah per tanaman, berat segar tanaman, indeks panen per tanaman.

Penelitian menggunakan Rancangan Acak Lengkap (RAL) pola faktorial (4 x 6), dengan 3 ulangan sehingga membentuk 72 unit percobaan. Faktor pertama (dosis arang sekam) pada 4 taraf yaitu A0 (kontrol), A1 (40 g arang sekam $/ 8 \mathrm{~kg}$ tanah), A2 (80 g arang sekam/8 kg tanah), A3 (120 g arang sekam $/ 8 \mathrm{~kg}$ tanah). Faktor kedua (dosis kombinasi pupuk kandang dan pupuk majemuk) pada 6 taraf yaitu B0 (Kontrol), B1 (100\% pupuk kandang), B2 (75\% pupuk kandang $+25 \%$ pupuk majemuk), B3 (50\% pupuk kandang $+50 \%$ pupuk majemuk), B4 (25\% pupuk kandang $+75 \%$ pupuk majemuk), B5 (100\% pupuk majemuk). Data dianalisis ragam dan diuji lanjut dengan Duncan's Multiple Range Test (DMRT) pada taraf $\alpha=5 \%$.

\section{Hasil dan Pembahasan}

\section{Tinggi Tanaman}

Hasil analisis ragam menunjukkan bahwa perlakuan dosis kombinasi pupuk kandang dengan pupuk majemuk growmore berpengaruh terhadap tinggi tanaman cabai rawit, sedangkan perlakuan dosis arang sekam dan interaksi antara dosis arang sekam dengan dosis kombinasi pupuk kandang dan pupuk majemuk tidak berpengaruh terhadap tinggi tanaman cabai rawit. Hasil uji jarak berganda Duncan perlakuan dosis arang sekam dan dosis kombinasi pupuk kandang dengan pupuk majemuk growmore pada parameter tinggi tanaman cabai rawit disajikan pada Tabel 1 .

Tabel 1. Tinggi Tanaman Cabai Rawit pada Perlakuan Dosis Arang Sekam dan Dosis kombinasi Pupuk Kandang dan Pupuk Majemuk Growmore

\begin{tabular}{|c|c|c|c|c|c|}
\hline \multirow{2}{*}{$\begin{array}{c}\text { Dosis Kombinasi Pupuk } \\
\text { Kandang:Pupuk Majemuk } \\
\text { Growmore }\end{array}$} & \multicolumn{4}{|c|}{ Dosis Arang Sekam (per $8 \mathrm{~kg}$ tanah) } & \multirow[b]{2}{*}{ Rata - rata } \\
\hline & $\begin{array}{c}\mathrm{A} 0 \\
\text { (Kontrol) }\end{array}$ & $\begin{array}{c}\mathrm{A} 1 \\
(40 \mathrm{~g}) \\
\end{array}$ & $\begin{array}{c}\mathrm{A} 2 \\
(80 \mathrm{~g}) \\
\end{array}$ & $\begin{array}{c}\mathrm{A} 3 \\
(120 \mathrm{~g}) \\
\end{array}$ & \\
\hline & \multicolumn{4}{|c|}{ - } & \\
\hline $\begin{array}{l}\text { B0 (Kontrol) } \\
\text { B1 (100\%:0\%) }\end{array}$ & $\begin{array}{l}53,67 \\
73,33\end{array}$ & $\begin{array}{l}65,00 \\
72,33\end{array}$ & $\begin{array}{l}66,00 \\
72,00\end{array}$ & $\begin{array}{l}59,33 \\
71,00\end{array}$ & $\begin{array}{l}61,00^{\mathrm{c}} \\
72,17^{\mathrm{ab}}\end{array}$ \\
\hline B2 $(75 \%: 25 \%)$ & 66,33 & 67,00 & 67,33 & 66,33 & $66,75^{\mathrm{bc}}$ \\
\hline B3 $(50 \%: 50 \%)$ & 75,67 & 66,33 & 82,33 & 77,67 & $75,50^{\mathrm{a}}$ \\
\hline B4 $(25 \%: 75 \%)$ & 70,00 & 65,33 & 72,00 & 80,33 & $71,92^{\mathrm{ab}}$ \\
\hline B5 $(0 \%: 100 \%)$ & 77,33 & 64,33 & 59,00 & 81,33 & $70,50^{\mathrm{ab}}$ \\
\hline Rata - rata & 69,39 & 66,72 & 69,78 & 72,67 & \\
\hline
\end{tabular}

Keterangan : superskrip berbeda pada kolom yang sama menunjukkan perbedaan nyata $(\mathrm{P}<0,05)$

Hasil uji jarak berganda Duncan menunjukkan bahwa perlakuan B0 tidak berbeda nyata dengan $\mathrm{B} 2$, namun berbeda nyata dengan $\mathrm{B} 1$, B3, B4 dan B5. Pemberian pupuk kandang dengan pupuk majemuk pada dosis kombinasi yang berbeda menghasilkan pertumbuhan tanaman yang lebih tinggi dibandingkan dengan tanpa pupuk kandang dan pupuk majemuk. Hal tersebut terjadi karena tanaman cabai rawit memperoleh suplai unsur hara yang cukup sehingga metabolisme tanaman menjadi lebih baik. Sesuai dengan pernyataan Tuapattinaya dan Tutupoly (2014) bahwa tinggi tanaman dipengaruhi oleh proses metabolisme yang mana aktifitas metabolisme tanaman membutuhkan nutrisi dari pemupukan. Tinggi tanaman dipengaruhi oleh tersedianya unsur hara nitrogen dan fosfat yang diserap oleh tanaman. Hidayat et al. (2013) menyatakan bahwa unsur 
nitrogen yang tersedia bagi tanaman dengan jumlah yang cukup dapat melancarkan metabolisme tanaman sehingga pertumbuhan batang semakin tinggi dan mempengaruhi jumlah daun. Nitrogen dan fosfor yang tersedia cukup besar bagi tanaman akan menunjang pertumbuhan tinggi tanaman dan diameter batang, namun bila ketersediaannya rendah dapat menyebabkan tanaman tumbuh kerdil (Nabilah et al., 2018).

Tinggi tanaman cabai rawit pada perlakuan B1, B3, B4 dan B5 nyata lebih tinggi dibandingkan dengan perlakuan B0 dan B2. Perlakuan 50\% pupuk kandang dan 50\% pupuk majemuk (B3) dengan tinggi tanaman $75,5 \mathrm{~cm}$ nyata lebih tinggi terhadap perlakuan $75 \%$ pupuk kandang dan 25\% pupuk

\section{Jumlah Buah Per Tanaman}

Hasil analisis ragam menunjukkan bahwa perlakuan dosis kombinasi pupuk kandang dengan pupuk majemuk growmore berpengaruh terhadap jumlah buah per tanaman cabai rawit, sedangkan majemuk (B2) $66,75 \mathrm{~cm}$. Hal ini diduga disebabkan oleh kombinasi pupuk kandang dan pupuk majemuk dengan komposisi dosis yang tepat dapat menyediakan unsur hara yang sesuai bagi kebutuhan tanaman sehingga meningkatkan pertumbuhan tanaman cabai rawit. Menurut Haryadi et al. (2015) tanaman dapat tumbuh dan berkembang dengan baik bila unsur hara yang dibutuhkan dalam jumlah cukup dan dalam bentuk yang siap diabsorbsi oleh akar tanaman. Sahetapy dan Liworngawan (2013) menyebutkan bahwa pupuk majemuk growmore mengandung unsur $\mathrm{Ca}, \mathrm{Mg}, \mathrm{Co}, \mathrm{Fe}, \mathrm{Mn}, \mathrm{Na}$ dan Zn yang dapat memperluas permukaan daun dan meningkatkan tinggi tanaman apabila digunakan dengan dosis yang tepat.

perlakuan dosis arang sekam dan interaksi antara dosis arang sekam dengan dosis kombinasi pupuk kandang dan pupuk majemuk tidak berpengaruh terhadap jumlah buah per tanaman cabai rawit.

Tabel 2. Jumlah Buah per Tanaman Cabai Rawit pada Perlakuan Dosis Arang Sekam dan Dosis Kombinasi Pupuk Kandang dan Pupuk Majemuk Growmore

\begin{tabular}{|c|c|c|c|c|c|}
\hline \multirow{2}{*}{$\begin{array}{l}\text { Dosis Kombinasi Pupuk } \\
\text { Kandang:PupukMajemuk } \\
\text { Growmore }\end{array}$} & \multicolumn{4}{|c|}{ Dosis Arang Sekam (per $8 \mathrm{~kg}$ tanah) } & \multirow[b]{2}{*}{ Rata - rata } \\
\hline & $\begin{array}{c}\mathrm{A} 0 \\
\text { (Kontrol) }\end{array}$ & $\begin{array}{c}\mathrm{A} 1 \\
(40 \mathrm{~g})\end{array}$ & $\begin{array}{c}\mathrm{A} 2 \\
(80 \mathrm{~g})\end{array}$ & $\begin{array}{c}\mathrm{A} 3 \\
(120 \mathrm{~g})\end{array}$ & \\
\hline & \multicolumn{4}{|c|}{--------------(buah/tanaman)-------------- } & \\
\hline B0 (Kontrol) & 24,00 & 24,00 & 36,00 & 42,67 & $31,67^{\mathrm{c}}$ \\
\hline B1 (100\%: : \%) & 39,00 & 43,00 & 55,67 & 32,00 & $42,42^{c}$ \\
\hline B2 $(75 \%: 25 \%)$ & 115,67 & 108,67 & 107,00 & 127,33 & $114,67^{b}$ \\
\hline B3 (50\% : 50\%) & 201,33 & 182,00 & 165,67 & 233,33 & $195,58^{\mathrm{a}}$ \\
\hline B4 $(25 \%: 75 \%)$ & 213,33 & 177,33 & 206,67 & 260,67 & $214,50^{\mathrm{a}}$ \\
\hline B5 (0 \% : 100\%) & 137,33 & 86,67 & 67,33 & 131,00 & $105,58^{\mathrm{b}}$ \\
\hline Rata - rata & 121,78 & 103,61 & 106,39 & 137,83 & \\
\hline
\end{tabular}

Keterangan : superskrip berbeda pada kolom yang sama menunjukkan perbedaan nyata $(\mathrm{P}<0,05)$

Berdasarkan Tabel 2. dapat diketahui bahwa perlakuan B3 tidak berbeda nyata dengan perlakuan B4 namun nyata lebih tinggi dengan perlakuan B0, B1, B2 dan B5, sementara perlakuan B2 tidak berbeda nyata dengan perlakuan B5 namun nyata lebih tinggi dengan perlakuan B0 dan B1. Hasil penelitian menunjukkan bahwa pemberian pupuk kandang dan pupuk majemuk menghasilkan jumlah buah per tanaman yang lebih banyak dibandingkan dengan perlakuan tanpa pemupukan. Pertumbuhan buah memerlukan zat hara terutama nitrogen, fosfor dan kalium. Nitrogen digunakan tanaman dalam pembentukan protein. Fosfor membantu dalam mempercepat pembentukan bunga, buah dan biji. Kalium berperan dalam pengangkutan karbohidrat, pembentukan dan pematangan buah. Pradita et al.
(2018) melaporkan bahwa pembentukan buah dipengaruhi oleh unsur hara $\mathrm{N}, \mathrm{P}$, dan $\mathrm{K}$. Pembentukan buah juga dipengaruhi oleh jumlah fotosintat yang dihasilkan dari proses fotosintesis. Menurut Pinasti et al. (2020) unsur hara sangat mempengaruhi pembentukan dan pengisian buah, unsur hara digunakan dalam proses fotosintesis yakni sebagai penyusun karbohidrat, lemak, protein, mineral serta vitamin yang akan ditranslokasikan ke bagian penyimpanan buah.

Komposisi kombinasi dosis antara pupuk kandang dengan pupuk majemuk berpengaruh terhadap pertumbuhan dan hasil produksi tanaman cabai rawit. Menurut Satriyo dan Aini (2018) tanaman akan tumbuh dan berproduksi dengan baik tergantung pada pupuk yang diberikan pada 
tanaman, apabila pupuk yang diberikan sesuai dengan kebutuhan tanaman maka tanaman dapat berproduksi dengan baik. Rinasari et al. (2016) menyebutkan bahwa pemberian kombinasi pupuk organik dengan pupuk anorganik pada perbandingan tertentu dapat meningkatkan kualitas dan kuantitas tanaman. Perlakuan 50\% pupuk kandang $+50 \%$ pupuk majemuk dan perlakuan $25 \%$ pupuk kandang $+75 \%$ pupuk majemuk memberikan hasil jumlah buah tertinggi dibandingkan dengan perlakuan lainnya. Hal ini dikarenakan pemberian dosis pupuk majemuk yang sama dengan atau lebih besar dibandingkan pada dosis pupuk kandang akan lebih cepat membantu menyediakan unsur hara yang dibutuhkan bagi tanaman. Pangaribuan et al. (2012) menyatakan bahwa kelemahan pupuk organik yaitu unsur hara yang sangat lambat tersedia sehingga dibutuhkan kombinasi dengan pupuk anorganik yang menyediakan unsur hara dengan cepat.

Tabel 3. Bobot Buah per Tanaman Cabai Rawit pada Perlakuan Dosis Arang Sekam dan Dosis Kombinasi Pupuk Kandang dan Pupuk Majemuk Growmore

\begin{tabular}{|c|c|c|c|c|c|}
\hline \multirow{2}{*}{$\begin{array}{c}\text { Dosis Kombinasi Pupuk } \\
\text { Kandang:PupukMajemuk } \\
\text { Growmore }\end{array}$} & \multicolumn{4}{|c|}{ Dosis Arang Sekam (per $8 \mathrm{~kg}$ tanah) } & \multirow[b]{2}{*}{ Rata - rata } \\
\hline & $\begin{array}{c}\mathrm{A} 0 \\
\text { (Kontrol) }\end{array}$ & $\begin{array}{c}\mathrm{A} 1 \\
(40 \mathrm{~g}) \\
\end{array}$ & $\begin{array}{c}\mathrm{A} 2 \\
(80 \mathrm{~g})\end{array}$ & $\begin{array}{c}\mathrm{A} 3 \\
(120 \mathrm{~g})\end{array}$ & \\
\hline & \multicolumn{4}{|c|}{ 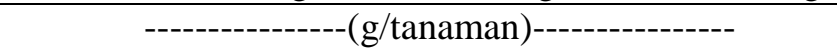 } & \\
\hline B0 (Kontrol) & 16,87 & 18,20 & 23,77 & 33,50 & $23,09^{c}$ \\
\hline B1 $(100 \%: 0 \%)$ & 26,56 & 28,62 & 35,10 & 21,43 & $27,93^{\mathrm{c}}$ \\
\hline B2 $(75 \%: 25 \%)$ & 81,18 & 74,15 & 56,94 & 79,09 & $72,84^{\mathrm{b}}$ \\
\hline B3 $(50 \%: 50 \%)$ & 134,95 & 132,01 & 122,73 & 135,35 & $131,26^{\mathrm{a}}$ \\
\hline B4 $(25 \%: 75 \%)$ & 126,39 & 118,33 & 131,08 & 170,82 & $136,66^{\mathrm{a}}$ \\
\hline B5 (0\%: $100 \%)$ & 89,88 & 55,47 & 43,65 & 87,18 & $69,04^{\mathrm{b}}$ \\
\hline Rata - rata & 79,31 & 71,13 & 68,88 & 87,89 & \\
\hline
\end{tabular}

Keterangan : superskrip berbeda pada kolom yang sama menunjukkan perbedaan nyata $(\mathrm{P}<0,05)$

\section{Bobot Buah Per Tanaman}

Hasil analisis ragam menunjukkan bahwa perlakuan dosis kombinasi pupuk kandang dengan pupuk majemuk growmore berpengaruh terhadap bobot buah per tanaman cabai rawit, sedangkan perlakuan dosis arang sekam dan interaksi antara dosis arang sekam dengan dosis kombinasi pupuk kandang dan pupuk majemuk tidak berpengaruh terhadap bobot buah per tanaman cabai rawit. Hasil uji jarak berganda Duncan perlakuan dosis arang sekam dan dosis kombinasi pupuk kandang dengan pupuk majemuk growmore pada parameter bobot buah per tanaman cabai rawit disajikan pada Tabel 3 .

Hasil uji jarak berganda Duncan menunjukkan bahwa perlakuan B4 tidak berbeda nyata dengan perlakuan B3 namun berbeda nyata dengan B0, B1, B2 dan B5, sedangkan perlakuan B0 tidak berbeda nyata dengan $\mathrm{B} 1$ namun berbeda nyata dengan perlakuan B2 dan B5, serta perlakuan B2 tidak berbeda nyata dengan perlakuan B5. Pemberian 50\% pupuk kandang $+50 \%$ pupuk majemuk serta $25 \%$ pupuk kandang $+75 \%$ pupuk majemuk memberikan hasil bobot buah pertanaman tertinggi yakni 131,26 g/tanaman dan 136,66 $\mathrm{g} / \operatorname{tanaman}$ dibandingkan pada perlakuan lainnya. Hal ini diduga karena pada formulasi dosis pupuk yang tepat yang dapat meningkatkan bobot buah cabai rawit. Perlakuan pemupukan secara signifikan berpengaruh terhadap bobot buah per tanaman cabai rawit. Pupuk majemuk menyediakan unsur hara N, $\mathrm{P}, \mathrm{K}$ pada tanaman cabai rawit yang dapat tersedia dan terserap sempurna oleh tanaman karena dalam media tanam mengandung bahan organik yang cukup yang berasal dari pupuk kandang sehingga pemberian pupuk majemuk lebih efektif. Menurut Suharja dan Sutarno (2009) pemberian pupuk organik dan pupuk kimia secara bersama-sama dapat menyediakan unsur hara $\mathrm{N}, \mathrm{P}, \mathrm{K}$ dan bahan organik sehingga mampu meningkatkan bobot buah tanaman cabai. Pupuk organik dapat memperbaiki sifat fisika, kimia dan biologi tanah serta mampu menyediakan unsur hara yang berguna bagi tanaman. Hal ini sesuai dengan Roidah ( 2013) bahwa pupuk kandang bermanfaat untuk mengembalikan ketersediaan unsur hara pada tanah sehingga dapat meningkatkan produksi yang maksimal bagi tanaman. Pemberian pupuk anorganik akan menambah dan melengkapi unsur hara yang bermanfaat dalam meningkatkan biomassa tanaman cabai rawit.

Bobot buah tanaman cabai berkaitan dengan besarnya fotosintat yang ditranslokasikan ke bagian buah cabai rawit. Menurut Prananti et al. (2018) unsur hara yang cukup tersedia akan mengoptimalkan proses fotosintesis dan asimilat yang dihasilkan dapat digunakan sebagai cadangan 
makanan dalam jaringan pada fase generatif, sehingga memungkinkan bobot buah menjadi lebih optimal. Hal ini juga didukung oleh Kartika et al. (2013) bahwa semakin meningkat fotosintat yang dihasilkan dan ditranslokasikan ke buah maka akan meningkatkan bobot panen. Berdasarkan hasil penelitian menunjukkan bahwa tanaman cabai rawit yang mampu menghasilkan buah dengan jumlah banyak akan menghasilkan bobot buah yang tinggi pula. Hal ini sesuai dengan Hapsari et al. (2017) bahwa semakin banyak jumlah buah, maka semakin tinggi bobot buah per tanaman yang akan dihasilkan.

Tabel 4. Berat Segar Tanaman Cabai Rawit pada Perlakuan Dosis Arang Sekam dan Dosis Kombinasi Pupuk Kandang dan Pupuk Majemuk Growmore

\begin{tabular}{|c|c|c|c|c|c|}
\hline \multirow{2}{*}{$\begin{array}{c}\text { Dosis Kombinasi Pupuk } \\
\text { Kandang:PupukMajemuk } \\
\text { Growmore }\end{array}$} & \multicolumn{4}{|c|}{ Dosis Arang Sekam (per $8 \mathrm{~kg}$ tanah) } & \multirow[b]{2}{*}{ Rata - rata } \\
\hline & $\begin{array}{c}\mathrm{A} 0 \\
\text { (Kontrol) }\end{array}$ & $\begin{array}{c}\text { A1 } \\
(40 \mathrm{~g})\end{array}$ & $\begin{array}{c}\text { A2 } \\
(80 \mathrm{~g})\end{array}$ & $\begin{array}{c}\mathrm{A} 3 \\
(120 \mathrm{~g})\end{array}$ & \\
\hline & \multicolumn{4}{|c|}{------------(g/tanaman)------------- } & \\
\hline B0 (Kontrol) & 29,67 & 30,33 & 25,67 & 51,17 & $34,21^{\mathrm{e}}$ \\
\hline B1 (100\%:0\%) & 44,17 & 62,00 & 57,33 & 64,83 & $57,08^{\mathrm{d}}$ \\
\hline B2 $(75 \%: 25 \%)$ & 78,17 & 82,67 & 76,33 & 86,17 & $80,83^{\mathrm{c}}$ \\
\hline B3 $(50 \%: 50 \%)$ & 102,83 & 122,00 & 131,33 & 134,67 & $122,71^{\mathrm{b}}$ \\
\hline B4 $(25 \%: 75 \%)$ & 127,67 & 137,67 & 163,33 & 226,33 & $163,75^{\mathrm{a}}$ \\
\hline B5 $(0 \%: 100 \%)$ & 100,33 & 86,00 & 106,00 & 139,50 & $107,96^{\mathrm{b}}$ \\
\hline Rata - rata & $80,47^{\mathrm{b}}$ & $86,78^{\mathrm{b}}$ & $93,33^{\mathrm{b}}$ & $117,11^{\mathrm{a}}$ & \\
\hline
\end{tabular}

Keterangan : superskrip berbeda pada kolom yang sama menunjukkan perbedaan nyata $(\mathrm{P}<0,05)$

\section{Berat Segar Tanaman}

Hasil analisis ragam menunjukkan bahwa perlakuan dosis arang sekam dan pemberian dosis kombinasi pupuk kandang dengan pupuk majemuk growmore berpengaruh terhadap berat segar tanaman cabai rawit, sedangkan interaksi antara dosis arang sekam dengan dosis kombinasi pupuk kandang dan pupuk majemuk tidak berpengaruh terhadap berat segar tanaman cabai rawit. Hasil uji jarak berganda Duncan perlakuan dosis arang sekam dan dosis kombinasi pupuk kandang dengan pupuk majemuk growmore pada parameter berat segar tanaman cabai rawit disajikan pada Tabel 4.

Hasil uji jarak berganda Duncan menunjukkan bahwa perlakuan A3 berbeda nyata dengan perlakuan A0, A1 dan A2. Perlakuan B4 memberikan hasil tertinggi dan berbeda nyata dari perlakuan B0, B1, B2, B3 dan B5, sedangkan perlakuan B3 tidak berbeda nyata dengan B5.

Pemberian $120 \mathrm{~g}$ arang sekam $/ 8 \mathrm{~kg}$ tanah (A3) memberikan hasil berat basah tanaman tertinggi yaitu 117,11 g/tanaman dibandingkan tanpa pemberian arang sekam. Hal ini diduga karena pemberian arang sekam mampu menjaga kelembaban tanah, menjadikan tanah lebih gembur sehingga menyediakan cukup udara serta mampu menahan ketersediaan unsur hara dan air sehingga dapat membantu mengoptimalkan akar dalam penyerapan unsur hara yang akan menunjang pertumbuhan tanaman. Menurut pernyataan Gustia (2013) arang sekam bersifat porous yang menyebabkan sirkulasi udara dalam tanah menjadi baik dan memiliki daya serap air yang tinggi serta bersifat steril sehingga dapat meningkatkan produksi tanaman. Pemberian arang sekam yang bermanfaat dalam menciptakan aerasi dan drainase tanah yang baik dinilai mampu memungkinkan unsur hara dan air yang terdapat dalam media tanam dapat dimanfaatkan dengan baik oleh tanaman. Naimnule (2016) menyebutkan pertumuhan akar yang baik dapat menyerap air dan unsur hara secara optimal sehingga mampu menunjang pertumbuhan tanaman. Bobot segar tanaman dipengaruhi oleh kandungan air yang terdapat dalam sel-sel tanaman. Tanari dan Vita (2017) menyatakan bahwa berat basah tanaman menunjukkan komposisi dari hara yang terkandung dalam jaringan tanaman dengan mengikut sertakan kandungan air.

Berat segar antara perlakuan B3 dan B5 tidak berbeda nyata, perlakuan $25 \%$ pupuk kandang + 75\% pupuk majemuk (B4) memberikan hasil berbeda nyata dan tertinggi $163,75 \mathrm{~g} /$ tanaman dibandingkan pada perlakuan lainnya, berat segar terendah terlihat pada B0/kontrol yakni 34,21 g/tanaman yang berbeda nyata dengan berat segar semua perlakuan. Hal ini diduga karena kombinasi tersebut mampu menyediakan unsur hara yang cukup bagi pertumbuhan tanaman. Unsur hara N, P, dan $\mathrm{K}$ yang terpenuhi akan menunjang pertumbuhan tanaman seperti pembentukan organ baru, meningkatkan tinggi tanaman, memungkinkan tanaman untuk berfotosintesis dengan optimal dan 
menghasilkan asimilat yang akan didistribusikan ke seluruh organ tanaman yang akan berpengaruh pada bobot tanaman. Prasetyo (2014) menyatakan besar kecilnya jumlah unsur hara yang diberikan dan diserap oleh tanaman sangat mempengaruhi laju pertumbuhan vegetatif, generatif dan fase produktif

\section{Indeks Panen Per Tanaman}

Hasil uji jarak berganda Duncan perlakuan dosis arang sekam dan dosis kombinasi pupuk kandang dengan pupuk majemuk growmore pada parameter indeks panen per tanaman cabai rawit disajikan pada Tabel 5.

Berdasarkan Tabel 5. dapat diketahui bahwa aplikasi dosis kombinasi pupuk kandang dengan pupuk majemuk berpengaruh terhadap indeks panen tanaman cabai rawit. Perlakuan B3 tidak tanaman, sehingga kecukupan unsur hara akan menentukan nilai biomassa suatu tanaman. Berat basah tanaman adalah bentuk dari hasil metabolisme tanaman selama masa pertumbuhan yang ditandai dengan bertambahnya bobot yang sifatnya irreversible.

berbeda nyata dengan perlakuan B2 dan B4 namun berbeda nyata dari perlakuan B0, B1 dan B5. Pemberian 50\% pupuk kandang $+50 \%$ pupuk majemuk (B3) memberikan persentase indeks panen tertinggi dibanding pada perlakuan lainnya yaitu sebesar $51,89 \%$. Hal ini diduga karena ketersediaan unsur hara tanaman cabai mampu tercukupi serta pemberian pupuk kandang dan pupuk majemuk menyediakan hara dalam bentuk tersedia bagi tanaman sehingga dapat meningkatkan indeks panen.

Tabel 5. Indeks Panen per Tanaman Cabai Rawit pada Perlakuan Dosis Arang Sekam dan Dosis Kombinasi Pupuk Kandang dan Pupuk Majemuk Growmore

\begin{tabular}{|c|c|c|c|c|c|}
\hline \multirow{2}{*}{$\begin{array}{c}\text { Dosis Kombinasi Pupuk } \\
\text { Kandang:PupukMajemuk } \\
\text { Growmore }\end{array}$} & \multicolumn{4}{|c|}{ Dosis Arang Sekam (per $8 \mathrm{~kg}$ tanah) } & \multirow[b]{2}{*}{ Rata - rata } \\
\hline & $\begin{array}{c}\text { A0 } \\
\text { (Kontrol) }\end{array}$ & $\begin{array}{c}\mathrm{A} 1 \\
(40 \mathrm{~g})\end{array}$ & $\begin{array}{c}\mathrm{A} 2 \\
(80 \mathrm{~g})\end{array}$ & $\begin{array}{c}\mathrm{A} 3 \\
(120 \mathrm{~g})\end{array}$ & \\
\hline & \multicolumn{4}{|c|}{--------------------(\%)-------------------- } & \\
\hline B0 (Kontrol) & 36,38 & 36,47 & 46,66 & 36,06 & $38,89^{\text {bcd }}$ \\
\hline B1 $(100 \%: 0 \%)$ & 37,62 & 31,20 & 37,90 & 24,94 & $32,92^{\mathrm{d}}$ \\
\hline B2 $(75 \%: 25 \%)$ & 51,33 & 46,49 & 40,88 & 48,15 & $46,71^{\mathrm{ab}}$ \\
\hline B3 $(50 \%: 50 \%)$ & 57,42 & 52,08 & 48,18 & 49,86 & $51,89^{\mathrm{a}}$ \\
\hline B4 $(25 \%: 75 \%)$ & 50,13 & 45,92 & 44,65 & 42,48 & $45,80^{\mathrm{abc}}$ \\
\hline B5 (0\%: $100 \%)$ & 48,11 & 37,96 & 27,85 & 37,84 & $37,94^{\mathrm{d}}$ \\
\hline Rata - rata & 46,83 & 41,69 & 41,02 & 39,89 & \\
\hline
\end{tabular}

Keterangan : superskip berbeda pada kolom yang sama menunjukkan perbedaan nyata $(\mathrm{P}<0,05)$

Unsur hara nitrogen dan fosfor merupakan unsur hara yang berperan penting dalam menentukan besarnya indeks panen yang dihasilkan tanaman. Puspadewi et al. (2016) menyatakan unsur hara nitrogen mampu meningkatkan jumlah daun, memperluas daun, memperbesar diameter batang, memperpanjang ruas batang sehingga akan meningkatkan berat brangkasan. Besarnya indeks panen bergantung pada kemampuan pertumbuhan suatu tanaman. Indeks panen juga dapat dipengaruhi oleh lama dan laju pertumbuhan tanaman. Menurut Wahyudin et al. (2015) nilai indeks panen sangat bergantung pada lama dan laju pertumbuhan relatif sebelum dan sesudah periode pembungaan yang dipengaruhi oleh faktor genetik dan lingkungan.

Indeks panen adalah perbandingan berat bagian tanaman yang bernilai ekonomis (berat buah per tanaman) dengan berat seluruh bagian tanaman. Menurut Sinaga et al. (2017) indeks panen merupakan suatu tolak ukur produktivitas suatu tanaman, tanaman dengan indeks panen rendah $(<0,40)$ menunjukkan tanaman tersebut

kurang produktif. Indeks panen menunjukkan efektivitas tanaman dalam memanfaatkan hasil fotosintesis. Purboningtyas et al. (2020) menyatakan bahwa indeks panen yang semakin tinggi menunjukkan bahwa fotosintat yang ditranslokasikan untuk fase vegetatif dan generatif khususnya pembentukan biji semakin banyak.

\section{Kesimpulan}

Berdasarkan hasil penelitian, dapat disimpulkan bahwa pemberian dosis kombinasi pupuk kandang dan pupuk majemuk secara keseluruhan berpengaruh terhadap parameter yang diamati. Pemberian $25 \%$ pupuk kandang $+75 \%$ 
pupuk majemuk dan penggunaan arang sekam 120 $\mathrm{g} / 8 \mathrm{~kg}$ tanah memberikan hasil yang baik pada pertumbuhan dan produksi cabai rawit.

\section{Daftar Pustaka}

Agustin, A. D., M. Riniarti dan Duryat. 2014. Pemanfaatan limbah serbuk gergaji dan arang sekam padi sebagai media sapih untuk Cempaka Kuning (Michelia champaca). J. Sylva Lestari, 2 (3) : 49 - 58.

Aini, C dan T. Wardiyati. 2018. Uji efektivitas arang sekam padi, jerami bakar dan pupuk kandang ayam terhadap pertumbuhan dan hasil bawang merah (Allium ascalonium L.). J. Produksi Tanaman, 6 (12) : 3086 3095.

BPS. 2015. Statistik Daerah Kecamatan Tembalang. Badan Pusat Statistika, Semarang.

BPS. 2020. Statistik Hortikultura 2019. Jakarta.

Damayanti, N.S., D.W. Widjajanto, Sutarno. 2019. Pertumbuhan dan produksi tanaman sawi Pakcoy (Brassica rapa L.) akibat dibudidayakan pada berbagai media tanam dan dosis pupuk organik. J. Agro Complex 3 (3) : $142-150$

Gustia, H. 2013. Pengaruh penambahan sekam bakar pada media tanam terhadap pertumbuhan dan produksi tanaman sawi (Brassica juncea L.). J. Kesehatan dan Lingkungan, 1 (1) : 12 - 17.

Hapsari, R., D. Indradewa dan E. Ambarwati. 2017. Pengaruh pengurangan jumlah cabang dan jumlah buah terhadap pertumbuhan dan hasil tomat (Solanum lycopersicum L.). Vegetalika, $6(3): 37-49$.

Haryadi, D., H. Yetti, dan S. Yoseva. 2015. Pengaruh pemberian beberapa jenis pupuk terhadap pertumbuhan dan produksi tanaman kailan (Brassica alboglabra L.). Jom Faperta $2(2): 1-10$.

Hidayat, T., W. Wardati, dan Armaini.2013. Pertumbuhan dan produksi sawi (Brassica juncea L.) pada inceptisol dengan aplikasi kompos tandan kosong kelapa sawit. J. Online Mahasiswa Fakultas Pertanian Universitas Riau, 1 (1) : 1 -9.

Kartika, E., Z. Gani dan D. Kurniawan. 2013. Tanggapan tanaman tomat (Lycopersicum esculentum. Mill) terhadap pemberian kombinasi pupuk organik dan pupuk anorganik. J. Bioplantae, 2 (3) : 122 - 131.

Lubis, R. A. 2017. Uji perbandingan varietas dan pengaruh interval waktu pemberian pupuk daun growmore terhadap pertumbuhan dan produksi tanaman Semangka. J. Eksaskta, 2 (2) : $96-100$.

Milla, Y. N., I. K. Widnyana, N. P. Pandawani. 2016. Pengaruh waktu pemberian pupuk mikoriza terhadap pertumbuhan dan hasil bawang merah (Allium ascalonicum L.). J. Agrimeta, 6 (12) : 66 - 76.

Nabilah, I., H. Yetti, dan S. Yoseva. 2018. Pengaruh pewiwilan dan pupuk pelengkap cair terhadap pertumbuhan dan hasil tanaman cabai rawit (Capsicum frutescens L.). JOM Faperta UR, 5 (1) : $1-14$.

Naimnule, M. A. 2016. Pengaruh takaran arang sekam dan pupuk kandang sapi terhadap pertumbuhan dan hasil Kacang Hijau (Vigna radiate, L.). J. Pertanian Konservasi Lahan Kering, 1 (4) : $118-120$.

Pangaribuan, D. H., M. Yasir, dan N. K. Utami. 2012. Dampak bokashi kotoran ternak dalam pengurangan pemakaian pupuk anorganik pada budidaya tanaman tomat. J. Agron. Indonesia, 40 (3) : $204-210$.

Pinasti, W., A. Haitami dan A. Alatas. 2020. Respon pemberian pupuk petroganik dan pupuk phonska terhadap pertumbuhan dan produksi tanaman cabai rawit (Capsicum frutescens L.) pada tanah ultisol. J. Green Swarnadwipa, 9 (2) : $345-353$.

Pradita, T. P., W. S. D. Yamika dan T. Sumarni. 2018. Pengaruh jarak tanam cabai rawit (Capsicum frutescens L.) dan populasi oyong (Luffa acutangula) dalam tumpangsari terhadap hasil tanaman cabai rawit. J. Produksi Tanaman, $6(1): 1-8$.

Prananti, F. R., Y. Sunaryo dan Darnawi. 2018. Pengaruh dosis pupuk bokasi kotoran kambing dan kotoran sapi terhadap hasil produksi tanaman tomat (Solanum lycopersicum L.) varietas New Mutiara F1. J. Ilmiah Agroust, 2 (2) : 1 - 9.

Prasetyo, R. 2014. Pemanfaatan berbagai sumber pupuk kandang sebagai sumber $\mathrm{N}$ dalam budidaya cabai merah (Capsicum annum $\mathrm{L}$.) di tanah berpasir. Plant Tropika Journal of Agro Science, 2 (2) : 125 - 132. 
Purboningtyas, D., K. Yurlisa dan B. Guritno. 2020. Pengaruh dosis pupuk kandang ayam terhadap pertumbuhan dan hasil dua varietas terung gelatik (Solanum melongena L.). J. Produksi Tanaman, 8 (2) : 216 - 225.

Puspadewi, S., W. Sutari dan Kusumiyati. 2016. Pengaruh konsentrasi pupuk organik cair (POC) dan dosis pupuk N, P, K terhadap pertumbuhan dan hasil tanaman jagung manis (Zea mays L. var Rugosa Bonaf) kultivar talenta. J. Kultivasi, 15 (3) : $208-216$.

Rinasari, S. P. O., Z. Kadir, dan Oktafiri. 2016. Pengaruh konsentrasi pupuk organonitrofos terhadap pertumbuhan dan produksi tanaman tomat (Lycopersicon esculentum Mill.) secara organik dengan sistem irigasi bawah permukaan (sub surface irrigation). J. Teknik Pertanian Lampung, 4 (4) : 325 - 234.

Roidah, I. S. 2013. Manfaat penggunaan pupuk organik untuk kesuburan tanah. J. Universitas Tulungagung Bonorowo, 1 (1) : $130-142$.

Sahetapy, M. dan G. A. Liworngawan. 2013. Respon Tanaman Seledri (Apium graveolens L.) pada dosis pupuk growmore. J. Ilmiah UNKLAB, 17 (1) : 33 -43 .

Satriyo, M. A. dan N. Aini. 2018. Pengaruh jenis dan tingkat konsentrasi pupuk daun terhadap pertumbuhan dan hasil tanaman Terong (Solanum melongena L.). J. Produksi Tanaman, 6 (7) : 1473 - 1480.

Sinaga, A. S., B. Guritno dan Sudiarso. 2017. Pengaruh dosis kompos sampah rumah tangga terhadap pertumbuhan dan hasil tiga varietas buncis tipe tegak (Phaseolus vulgaris L.). J. Produksi Tanaman, 5 (6) : 947 - 956.

Tanari, Y dan V. Vita. 2017. Pengaruh naungan dan berbagai media tanam terhadap pertumbuhan dan produksi tanaman selada (Lactuca sativa L.). J. AgroPet, 14 (2) : 1 - 12.

Tuapattinaya, P. M. J. dan F. Tutupoly. 2014. Pemberian pupuk kulit pisang raja (Musa sapientum) terhadap pertumbuhan dan produksi tanaman cabai rawit (Capsicum frutescens L.). Biopendix, 1 (1) : 13 - 21.

Wahyudin, A., Ruminta dan D. C. Bachtiar. 2015. Pengaruh jarak tanam berbeda pada berbagai dosis pupuk organik terhadap pertumbuhan dan hasil jagung hibrida P-12 di jatinangor. J. Kultivar, 14 (1) : $1-8$. 